\title{
Cyto-Morphological Particularities of Hair Cuticle in Domestic and Wild Suidae
}

\author{
Mirela E. CADAR*, Vioara MIREŞAN, Camelia RĂDUCU, Ilie CORNOIU, \\ Ionel TOADER, Anamaria VÂTCĂ
}

Faculty of Animal Science and Biotechnologies, University of Agricultural Sciences and Veterinary Medicine, 3-5 Mănăştur Street, 400372 Cluj-Napoca, Romania

*Corresponding author, email: mirucadar@yahoo.com

Bulletin UASVM Animal Science and Biotechnologies 71(2) / 2014,

Print ISSN 1843-5262; Electronic ISSN 1843-536X

DOI:10.15835/buasvmcn-asb:10485

\begin{abstract}
We want to put into evidence some particularities of hair cuticle in domestic and wild Suidae, using an own technical procedure for fluorescence microscopy. Also, we were interested if could exist any hair structural correlations between the investigated species. We conclude that the hair cuticle examination could be an important criterion, practically the easiest one, to identify a species, especially in human or veterinary forensic expertise.
\end{abstract}

Keywords: hair cuticle, cyto-morphological particularities, Suidae

Introduction. Among wild and domestic species, Hausman (1980) and Paliu et al. (1979) conceived a unique classification for hair cuticle types depending on evaluated body region and type of hair fibers. In veterinary medicine, there is a situation when the microscopic study of hair fibers' structure became a necessary complementary examination beside the expertise to establish the animal species from which derives a meat sample, on which surface it is practically impossible to not persist some hair fibers.

Aims and objectives. The aim of this study was to observe the microscopic structure of hair fiber in Suidae, especially of hair cuticle to put into evidence both species particularities and those ones, which could depend on breed. Also, we were interested if could exist any structural correlation between the hair of the investigated wild species and domestic one.

Materials and methods. There were collected primary undivided hair fibers only from shoulder blade region of 6 individuals from Suidae family (2 males of Sus scrofa ferrus species and 4 males of Sus scrofa domestica species Mangalitza breed) belonging to Balc Forestry Domain (Bihor County) and a private pig farm from same zone. The animals were healthy and in good maintenance condition. The micrometric measurements were done using the Zeiss micrometer eyepiece method: hair fiber diameter $(\mathrm{D}, \mu \mathrm{m})$; medullar diameter $(M, \mu m)$, height of cuticle cells $(E, \mu m)$. With these values were calculated the medullary index (im, $M / D$ ) and the cuticle index (ic, E/D). We put into evidence the outline of hair cuticle cells using an own examination procedure based on fluorescent microscopy (Bancroft and Steven, 1996; Cadar, 2009). Examination and microphography were done using fluorescent microscopy, optical variant with Ultropac for MC-1 microscope (IOR Bucharest) with adaptor for Canon PowerShot A95 camera (Mureșan et al., 1974).

Results and discussion. In wild boars, the hair fiber length was in average of $10 \mathrm{~cm}$ and in domestic pigs (Mangalitza breed) the hair fiber length was in average of $7 \mathrm{~cm}$. The micrometric measurements are mentioned in Table 1.

In case of domestic pig, Kshirsagar et al. (2009) founded an average of shaft diameter of $120 \mu \mathrm{m}$, and a medullary index of 0.66 , values greater than ours with $56.86 \%$, respectively 
Tab. 1. Micrometric values of hair fibers in studied species

\begin{tabular}{ccccccc}
\hline Species & $\mathbf{D}(\mu \mathrm{m})$ & $\mathbf{M}(\mu \mathrm{m})$ & $\mathbf{i m}$ & $\mathbf{C}(\mu \mathrm{m})$ & $\mathbf{E}(\mu \mathrm{m})$ & ic \\
\hline Wild boars & $80-100$ & $30-40$ & $0.375-0.400$ & $25-30$ & 14 & $0.175-0.140$ \\
\hline $\begin{array}{c}\text { Domestic, } \\
\text { Mangalitza breed }\end{array}$ & $69-84$ & $25-32$ & $0.362-0.380$ & $22-26$ & 9 & $0.130-0.107$ \\
\hline
\end{tabular}

$\mathbf{D}=$ hair fiber diameter; $\mathbf{M}=$ medullar diameter; $\mathbf{i m}=$ medullary index (M/D);

$\mathbf{C}=$ cortical thickness; $\mathbf{E}=$ height of hair cuticle cells; $\mathbf{i c}=$ cuticular index (E/D).

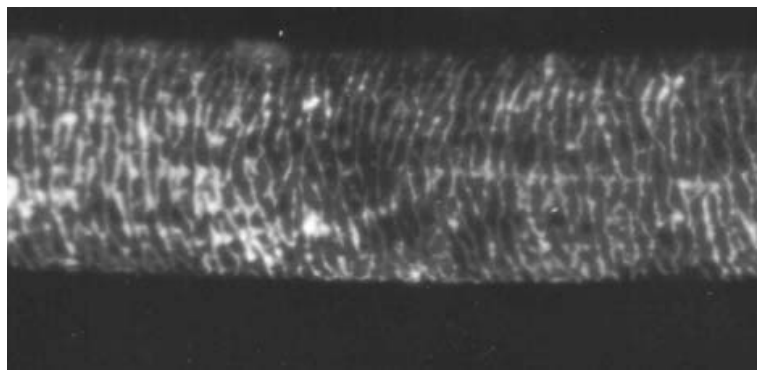

Fig. 1. Wild boar (Sus scrofa ferus species)

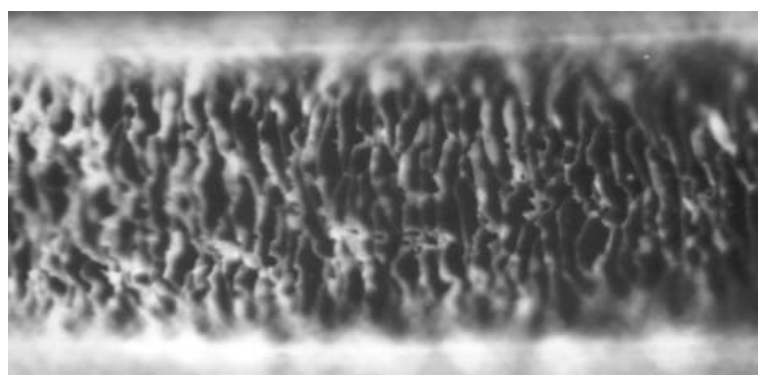

Fig, 2. Domestic pig, Mangalitza breed

$53.48 \%$, more possible depending on breed. From these data comes out that hair fibers with larger diameter $(69-84 \mu \mathrm{m})$ and relatively thin medulla $(25-32 \mu \mathrm{m})$ have the medullary index more reduced (0.362-0.380). In case of thick hair fibers, we observed that cortical zone covers 40 $60 \%$ of diameter and the medullar one was always multiserial. In measured diameters was included also the hair cuticle, being formed by a single layer of cells very thin.

As structural microscopic aspect, in wild boars, the hair fiber cuticle is of denticulate type, with narrow and transversally very oblong, and towards adjacent cells send out numerous short and sharp prolongations. In domestic pigs, the hair fiber cuticle is of denticulate type too, but with wider and shorter cells than those ones in wild boars, and with rare but more voluminous prolongations.

Conclusion. The cyto-morphology of hair fiber could be the essential element, but not the only one, to establish the species. Are also important the medullar type and micrometric measurements of hair fibers. We found few differences between the investigated species as concern micrometric values and microscopic aspects because of their wild and domestic.

\section{REFERENCES}

1. Bancroft G, Stevens A (1996). Theory and Practice of Histological Techniques. Ed. Churchill-Livingstone New York.

2. Cadar Mirela E (2009). Cyto-morphological particularities of hair cuticle in ruminants. Bulletin UASVM Cluj Animal Science and Biotechnologies 66(1-2): 32-34.

3. Hausman LA (1980). Structural characteristics of the hair of mammals. Amer. Nat. 44:496.

4. Kshirsagar SV, Singh B, Fulari SP (2009). Comparative Study of Human and Animal Hair in Relation with Diameter and Medullary index. Indian Journal of Forensic Medicine and Pathology 3: 105-108.

5. Mureşan E, Gaboreanu M, Bogdan AT, Baba AI (1974). Tehnici de histologie normală și patologică. Ed. Ceres București.

6. Paliu L, Liguereux J, Barrat I (1979). Identification des pails des mammifères Pyrenéeus. Ed. Vigot Paris. 